\title{
Tophaceous gout of the spine: a neurosurgical standpoint
}

\author{
Carlos Augusto Ferreira Lobão', Albedy Moreira Bastos², \\ Rafael Brito Santos ${ }^{1}$, Eduardo Anderson Duarte Cavalcante ${ }^{3}$ \\ Universidade Federal do Pará (UFPA), Belém, PA, Brazil, and Instituto de Saúde da Mulher, Belém, PA, Brazil.
}

\begin{abstract}
Objective: The study aim is to present the clinical, radiological aspects and treatment of this disease from the neurosurgical standpoint using a literature review and an illustrative case. Methods: A PubMed research was done with the terms "tophaceous gout", "spine", and "diagnosis". We reviewed these articles and compared it with an illustrative case here presented. Results: According to a research done, this is the fifty-second case of tophaceous gout of the spine described in the English literature. The case and literature review presented demonstrate the difficulty in diagnosis, especially when the patient has no previous history of gout. Conclusion: It is important to consider tophaceous gout of the spine among the differential diagnoses that occur in the spine. Clinical and neurosurgical treatment may be required considering each case.
\end{abstract}

\section{KEYWORDS}

Arthritis gout, spine, diagnosis.

\section{RESUMO}

Tofo gotoso de coluna vertebral: um ponto de vista neurocirúrgico

Objetivo: O objetivo deste estudo é apresentar a clínica, os aspectos radiológicos e o tratamento dessa afecção do ponto de vista neurocirúrgico, utilizando uma revisão da literatura e um caso ilustrativo. Métodos: Foi realizada uma pesquisa no PubMed com os termos "tophaceous gout", "spine", e "diagnosis". Analisamos os artigos e comparamos com um caso ilustrativo aqui apresentado. Resultados: De acordo com pesquisa realizada, este é o $52^{\circ}$ caso de tofo gotoso de coluna vertebral descrito na literatura. $O$ caso ilustrativo e a revisão de literatura aqui apresentados demonstram a dificuldade no diagnóstico, especialmente quando o paciente não tem história prévia de gota. Conclusão: É importante levar em consideração o tofo gotoso de coluna entre os diagnósticos diferenciais de doenças que acometem a coluna vertebral. Tratamentos clínicos e neurocirúrgicos podem ser necessários considerando cada caso.

\section{PALAVRAS-CHAVE}

Artrite gotosa, coluna vertebral, diagnóstico.

1 Neurosurgeon, Instituto de Saúde da Mulher, Belém, PA, Brazil.

2 Professor, Division of Neurology, Universidade Federal do Pará (UFPA), Belém, PA, Brazil.

3 Academic Medicine, UFPA, Belém, PA, Brazil. 


\section{Introduction}

Tophaceous gout is a metabolic disorder that results in the deposition of monosodium urate crystals in the joints and periarticular tissues. ${ }^{1}$ Usually, the primary manifestation of this disease is restricted to the peripheral skeleton. However, unusual locations have been described. The involvement of the axial skeleton is a rare finding and can result in neurologic symptoms. ${ }^{2}$ When it occurs, the patient may present with local pain, motor and sensory deficits and sphincter disturbances by compression of nerve roots and spinal cord.

In the present study, we report a case of tophaceous gout of the thoracic spine, characterized by severe back pain without previous systemic or appendicular skeleton manifestations of gout. In addition, we reviewed the literature concerning the topic, highlighting the clinical presentation, radiological aspects and neurosurgical approaches for the disease.

\section{Materials and methods}

We made a PubMed research with the terms "tophaceous gout", "spine", and "diagnosis" ranging the last 10 years. These articles were reviewed and those articles containing tophaceous gout of the spine case reports, clinical and radiological presentation and management were gathered, compared and analyzed.

An illustrative case of a patient with this pathology treated at our institution was reviewed based on patient's medical records and imaging exams. The patient consented with the realization of this research and publication of its results, according to the resolution 196/96 on research involving human subjects.

Considerations about what can be currently found in the literature and what we found in our illustrative case were done. We highlight important issues about tophaceous gout of the spine diagnosis and management from a neurosurgical standpoint.

\section{Illustrative case}

A 49-year-old man with history of severe back pain since a month before was referred to our hospital. Medical examination revealed no signs of arthritis in the appendicular skeleton, just pain on palpation of dorsal and lumbar paravertebral muscles. Magnetic resonance imaging (MRI) of the spine showed an expansive process involving the epidural space and posterior elements of T7 vertebrae (Figure 1).
Decompressive laminectomy from $\mathrm{T} 7$ to $\mathrm{T} 8$ and microsurgery for complete resection of the lesion was performed. Samples for histopathological analysis were collected that revealed granulomatous tissue containing crystals of urate in needle-shaped, a finding consistent with the diagnosis of gout. Post-operatively the patient presented considerable reduction of back pain. However, the non-adherence to the clinical treatment prescribed resulted in the appearance of the first signs of systemic manifestation of gout. The patient developed swelling and localized pain in the joints, mainly in left ankle and hallux. Rheumatologic treatment was initiated with colchicine and allopurinol with systemic disease control. Nowadays he is under neurosurgical and rheumatologic ambulatory follow up. Control MRI of the thoracic spine performed 6 months after surgery showing no lesion recurrence (Figure 2).

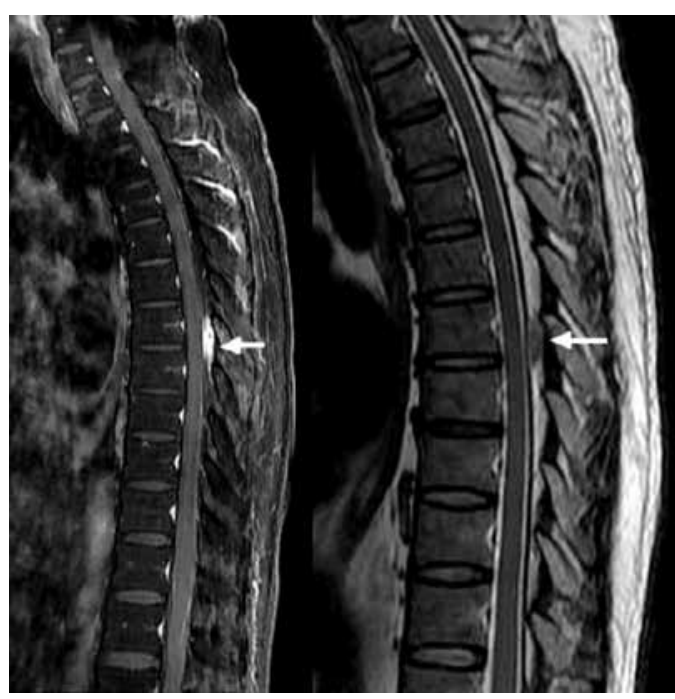

Figure 1 - Preoperative MRI of the thoracic spine showing expansive process in the epidural space T7 and T8.

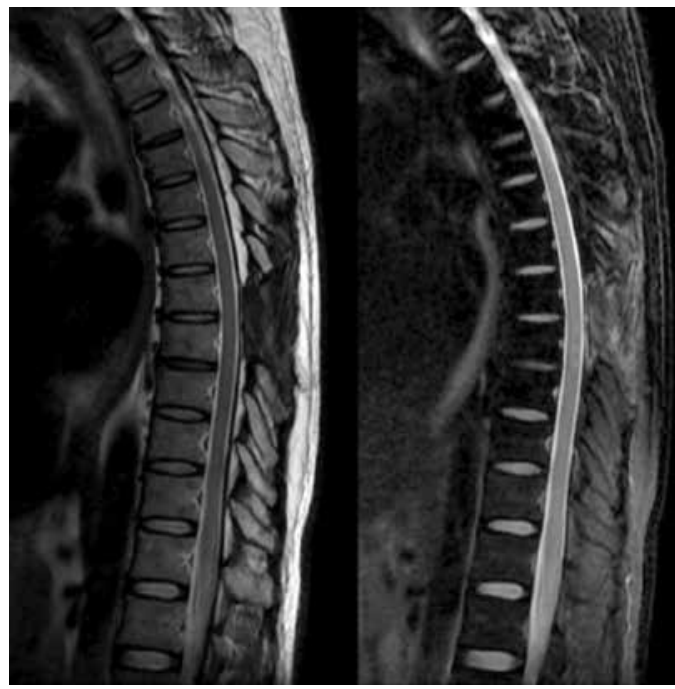

Figure 2 - Postoperative imaging after T7-T8 laminectomy and microsurgery for lesion resection with no recurrence. 


\section{Discussion}

Gout typically follows a clinical course characterized by years of asymptomatic hyperuricemia, followed by intermittent acute attacks, chronic arthritis and eventual formation of tophi, which are collections of monosodium urate crystals deposited in the subcutaneous tissue. ${ }^{3}$ Hyperuricemia occurs when urate levels are above $7 \mathrm{mg} / \mathrm{dL}$ in men and postmenopausal women and above $6 \mathrm{mg} / \mathrm{dL}$ in premenopausal women. ${ }^{4}$

The initial manifestation of gout usually involves the lower extremities, typically the first metatarsophalangeal joint that happens in approximately $50 \%$ of cases. ${ }^{2}$ The reason for this involvement is related to the low solubility of the crystals in areas of lower temperatures, resulting in formation of tophi preferentially in sites with low blood perfusion. ${ }^{5}$

Axial skeleton involvement is rare, with few cases reported in the literature. ${ }^{6}$ The most common location is the lumbar spine, followed by cervical and thoracic spine, ${ }^{7}$ the sacroiliac joints is sometimes also involved. ${ }^{8}$ The affected anatomical components of the spine are usually the vertebral bodies, ${ }^{9}$ pedicle, laminae, interapophyseal cartilage, ${ }^{10}$ and sometimes intradural and epidural spaces. ${ }^{11}$

Clinical presentation may vary from severe back pain to most serious neurological symptoms caused by spinal cord compression, as paraparesis and tetraparesis. ${ }^{12}$ The sacroiliac involvement may present with acute sacroiliitis and referred pain in the back, thigh or hip. ${ }^{13}$ The tophaceous gout of the odontoid process, although rarer, can cause paralysis of lower cranial nerve ${ }^{14}$ and atlanto-axial subluxation mimicking rheumatoid arthritis. ${ }^{15}$ Even though, it is important to emphasize that that axial involvement may be asymptomatic and biopsy is the only way to make a definitive diagnosis. ${ }^{16}$

Patients who present tophaceous gout of the spine generally have evidence of peripheral arthritis. However, as in the illustrative case reported here, there may be axial involvement in the absence of peripheral findings. ${ }^{17,18}$ A literature review published in 2004 stated that $30 \%$ of axial gout published cases has not had a previous history of peripheral skeleton gout. ${ }^{4}$

Most patients with axial gout are between 50 and 70 years, without male predominance. Although gout is traditionally considered a disease of men, it has been observed that postmenopausal women have the same incidence or even higher incidence than men of similar age. ${ }^{6}$

The pathogenesis of axial skeleton involvement by gout is unknown. It has been reported that factors like degenerative disease of the spine, tissue necrosis, or other previous injuries to the spine may be predisposing factors to the deposition of monosodium urate crystals. ${ }^{4,19}$ This hypothesis correlates low binding of plasma proteins to urate crystals in a reduced blood $\mathrm{pH}$ environment that results in the sedimentation of these crystals. What follows is a local inflammatory response and tophus formation. ${ }^{5}$

The initial diagnosis of tophaceous gout of the spine becomes difficult because its clinical and radiological presentation is similar to other spine diseases like primary bone tumors, metastases, infectious granulomas and other inflammatory pathologies. ${ }^{20}$

Plain radiographs of the spine in gout may be normal or show nonspecific degenerative changes. Computed tomography may present bone erosion with periarticular tophi around the articular processes. These signs would represent a chronic joint injury more characteristic of gout than of degenerative processes. MRI may show homogeneous intermediate-to-low signal intensity on T1-weighted images. On T2-weighted sequences a continuum of alterations may occur ranging from homogeneous high to homogeneous low signal intensities. After gadolinium administration, the tophi can show variable enhancement that varies from homogeneous to heterogeneous peripheral enhancement. These findings are not specific and can also be found in infectious and other inflammatory diseases of the axial skeleton. ${ }^{21}$

Most cases of tophaceous gout of the spine causing neural compression must be managed with decompressive surgery generally resulting in good results. ${ }^{4}$ Often this procedure is performed without previously suspected diagnosis of gout. In this way it is common that tophaceous gout of the spine be diagnosed only after surgery through pathological samples examination. Another indication for surgery is the need to differentiate the lesion from other possible pathologies that need specific treatment. Situations like that may happen in infections that requires drainage and sampling cultures, and neoplastic diseases that requires complimentary treatment. ${ }^{5}$

Surgical treatment should be performed taking into consideration the degree of neural compression, the involvement of spine joints, and the presence of spinal instability, in addition to patient age, lifestyle and comorbidities. Decompressive surgery should be considered whenever there is neural compression. Spinal fixation using adequate techniques must be considered whenever there is spinal instability. Surgery is also important for providing material collection for analysis. Taking it all together and considering the resection of the local inflammatory process by surgery it is adequate to say that surgery, when well indicated, reliefs clinical symptoms and improves patient quality of life. ${ }^{22}$

Intra-operatively, the tophus is seen as an abnormal deposit of a white substance with aspect of chalk, gritty and granulous. Furthermore, the accumulation of urate crystals is described like grainy materials, yellow in color with a consistency of cheese. Although gouty lesion has an appearance of white chalk, intra-operatively it can also be seeing as purulent. ${ }^{22}$ 
In pathological macroscopic examination gouty tophi have nodular appearance, chalky white in the center, constituted of monosodium urate crystals, proteins and mucopolysaccharides. Microscopically, urate deposits are negatively birefringent under polarized light and surrounded by multinucleated histiocytes, which are basically giant cells with foreign bodies, lymphoplasmacytic cells, and fibroblasts. ${ }^{4}$

In selected cases, surgery can be avoided if there is suspicion of systemic gout preoperatively. This suspicion may be based on the existence of peripheral manifestations of gout. Furthermore, patients presenting image findings suggesting gout of the axial skeleton may be clinically treated empirically. ${ }^{23}$ Thus, drug treatment may play a potential role avoiding the need for surgery. The follow up of pharmacological treatment alone can be done observing tophus regression on serial MRI. ${ }^{24}$

If the surgery is to be avoided, there is the possibility of keeping only medical treatment with analgesics, NSAIDs, the possible use of orthoses, and specific treatment for systemic gout. Colchicine is a potential drug in the systemic treatment of this disease, and one should consider its adverse effects that are noted in up to $80 \%$ of patients and includes nausea, vomiting and diarrhea. ${ }^{25}$

\section{Conclusions}

Involvement of the axial skeleton by gout is rare. Its occurrence without systemic manifestations or appendicular skeleton symptoms makes it even more unique, like the case presented here. It is necessary that the neurosurgeon keeps in mind this condition when dealing with other spine diseases and distinguish it from other inflammatory pathologies, infectious and neoplastic processes which are by far more common.

\section{Competing}

The authors declare that they have no competing interests.

\section{References}

1. Terkeltaub RA. Clinical practice. Gout. N Engl J Med. 2003;349(17):1647-55.

2. Ning TC, Keenan RT. Unusual clinical presentations of gout. Curr Opin Rheumatol. 2010;22(2):181-7.

3. Neogi T. Clinical practice. Gout. N Engl J Med. 2011;364(5):443-52.

4. Draganescu M, Leventhal LJ. Spinal gout: case report and review of the literature. J Clin Rheumatol. 2004;10(2):74-9.

5. Lam HY, Cheung KY, Law SW, Fung KY. Crystal arthropathy of the lumbar spine: a report of 4 cases. J Orthop Surg (Hong Kong). 2007;15(1):94-101.
6. Marinho F, Zeitoun-Eiss D, Renoux J, Brasseur JL, Genestie C, Grenier P. Tophaceous gout of the spine: case report and review of the literature. J Neuroradiol. 2012;39(2):123-6.

7. Konatalapalli RM, Demarco PJ, Jelinek JS, Murphey M, Gibson M, Jennings B, et al. Gout in the axial skeleton. $J$ Rheumatol. 2009;36(3):609-13.

8. Alarcón-Segovia DA, Cetina JA, Díaz-Jouanen E. Sarcroilaic joints in primary gout. Clinical and roentgenographic study of 143 patients. Am J Roentgenol Radium Ther Nucl Med. 1973;118(2):438-43.

9. Fenton P, Young S, Prutis K. Gout of the spine. Two case reports and a review of the literature. J Bone Joint Surg Am. 1995;77(5):767-71.

10. Hall MC, Selin G. Spinal involvement in gout: a case report with autopsy. J Bone Joint Surg. 1960;42:341-3.

11. van de Laar MA, van Soesbergen RM, Matricali B. Tophaceous gout of the cervical spine without peripheral tophi. Arthritis Rheum. 1987;30(2):237-8.

12. Marsaudon E, Bouchard C, Langand D. Spinal cord compression due to tophaceous vertebral gout: a case report and literature review. Rev Med Interne. 1999;20(3):253-7.

13. Saketkoo LA, Robertson HJ, Dyer HR, Virk ZU, Ferreyro HR, Espinoza LR. Axial gouty arthropathy. Am J Med Sci. 2009;338(2):140-6.

14. Tran A, Prentice D, Chan M. Tophaceous gout of the odontoid process causing glossopharyngeal, vagus, and hypoglossal nerve palsies. Int J Rheum Dis. 2011;14(1):105-8.

15. Wazir NN, Moorthy V, Amalourde A, Lim HH. Tophaceous gout causing atlanto-axial subluxation mimicking rheumatoid arthritis: a case report. J Orthop Surg (Hong Kong). 2005;13(2):203-6.

16. Hsu CY, Shih TT, Huang KM, Chen PQ, Sheu JJ, Li YW. Tophaceous gout of the spine: MR imaging features. Clin Radiol. 2002;57(10):919-25.

17. Paquette S, Lach B, Guiot B. Lumbar radiculopathy secondary to gouty tophi in the filum terminale in a patient without systemic gout: case report. Neurosurgery. 2000;46(4):986-8.

18. Varga J, Giampaolo C, Goldenberg DL. Tophaceous gout of the spine in a patient with no peripheral tophi: case report and review of the literature. Arthritis Rheum. 1985;28(11):1312-5.

19. Beier CP, Hartmann A, Woertgen C, Brawanski A, Rothoerl RD. A large, erosive intraspinal and paravertebral gout tophus. Case report. J Neurosurg Spine. 2005;3(6):485-7.

20. Hasturk AE, Basmaci M, Canbay S, Vural C, Erten F. Spinal gout tophus: a very rare cause of radiculopathy. Eur Spine J. 2012;21(Suppl 4):400-3.

21. Yu JS, Chung C, Recht M, Dailiana T, Jurdi R. MR imaging of tophaceous gout. AJR Am J Roentgenol. 1997;168(2):523-7.

22. Lu F, Jiang J, Zhang F, Xia X, Wang L, Ma X. Lumbar spinal stenosis induced by rare chronic tophaceous gout in a 29-year-old man. Orthopedics. 2012;35(10):e1571-5.

23. Barrett K, Miller ML, Wilson JT. Tophaceous gout of the spine mimicking epidural infection: case report and review of the literature. Neurosurgery. 2001;48(5):1170-2.

24. Dhôte R, Roux FX, Bachmeyer C, Tudoret L, DaumasDuport C, Christoforov B. Extradural spinal tophaceous gout: evolution with medical treatment. Clin Exp Rheumatol. 1997;15(4):421-3.

25. Kim KY, Ralph Schumacher $\mathrm{H}$, Hunsche E, Wertheimer Al, Kong SX. A literature review of the epidemiology and treatment of acute gout. Clin Ther. 2003;25(6):1593-617.

\footnotetext{
Correspondence address

Carlos Augusto Ferreira Lobão

Av. Governador Magalhães Barata, 1027,

ap. 2002, Nazaré

66063-240 - Belém, Pará, Brazil

E-mail: caflobao@yahoo.com.br
} 